\title{
Proposed Strategy for Pharmaceutical Industry (Case Study: PT Bio Farma Persero)
}

\author{
Reynaldy Prayogi, and Harimukti Wandebori
}

\begin{abstract}
PT Bio Farma (Persero) is a state-owned company that runs its business in the pharmaceutical industry, namely Vaccines and Anti-Sera products, so it has an important role to play in improving the quality of life in Indonesia. In addition, Bio Farma already has the capability to export its products because it already has WHO pre-qualifications.

PT Bio Farma (Persero) in distributing its products has two market sectors, namely the domestic and international sectors. In running its business, the company has several busines issue, namely Halal Product Regulation, High Rate of Raw Materials, Declining of Export Sales, Polio Eradication, and Global Covid Outbreak.

To analyze the internal condition, it used PESTEL analysis, Porter Five Forces and Competitor Analysis. To analyze the external condition, it used Resource Analysis and Value Chain Analysis are used. From all of these analyzes, a SWOT Analysis will be obtained to formulate the right strategy, and to propose Corporate, Business, and Functional Strategies that can be carried out by the company.

The right corporate strategy is the Diversification Strategy, this strategy aims to develop the company's products and markets to increase its competitiveness. Meanwhile, the right Business Strategy is Integrated Cost Leadership/Differentiation, this strategy aims to provide unique value to the company's products and create value chain efficiency.
\end{abstract}

Index Terms - Business Strategy, Corporate Strategy, SWOT Analysis, Vaccines.

\section{INTRODUCTION}

Migas and Non-Migas Processing Industry have become an industry that has the biggest contribution to the growth of Indonesia's Gross Domestic Product (GDP). In 2019, it was noted that this industry had a contribution of $19.7 \%$. The Non-Oil and Gas Industry itself has a greater percentage of GDP distribution compared to the Oil and Gas Industry because it has a distribution value of $17.58 \%$. Non-oil and gas industry in Indonesia consist of many industries. Based on statistical data from BPS Indonesia, the Food and Beverage Industry, the Textile Industry, the Chemical Industry, the Pharmaceutical and Traditional Medicine Industries, and the Metal Goods Industry have the most significant.

PT Bio Farma (Persero) is the only company that manufactures that producing vaccines in Indonesia. The company was first established in the Dutch colonial era, but over time finally, Bio Farma became a State-Owned Enterprise, which was legalized in 1997 based on Government Regulation No. 1/1997. Bio Farma in running its business, has three product lines in production, namely
Vaccines, Anti-Sera, and Diagnostics, but it focuses on Vaccines and Anti-Sera.

PT Bio Farma is currently moving towards Life Science and is the only company that manufactures vaccines for humans in Indonesia. And they focus all of its Company Resources to produce Final Product of Vaccines and AntiSera and Bulk that have the international quality to realize Indonesian people who have better health quality. But in the last four years, Bio Farma has experienced a decline in sales of its Virus Vaccine products, while for Anti-Sera and Diagnostic products, it has been running normally.

\section{A. Business Issue}

PT Bio Farma (Persero) is a state-owned company that is the only company that runs its business in producing vaccines in Indonesia. Given that the current level of interest in the use of vaccines has increased and the government has required vaccines in steps to improve the quality of life of the people of Indonesia, Bio Farma has an important role in helping these government objectives. Based on the data collection, it is known that Bio Farma is experiencing several problems, namely the Regulation of Halal Product, High Rate of Importing Raw Material, Declining in Export Sales because Polio Eradication, and Global Covid Outbreak. So the company has to immediately create and implement the suitable strategy that can improve its performance to overcome the business issue.

So, PT Bio Farma (Persero) certainly must immediately Based on these problems PT Bio Farma (Persero) has to immediately solve their business issue. Like improving the company's capabilities in order to compete in domestically or globally. So, in this research, author will propose the strategy that suitable for the company to overcome their Business Issue.

\section{B. Research Objective}

The purpose of this research is to propose an appropriate strategy for PT Bio Farma (Persero) in dealing with global competition by paying attention to Vaccine Commodity to increase market share on a global market and increase sales of Vaccine products from PT Bio Farma (Persero). To carry out the proposed strategy, the writer will analyze the business situation internally or externally to determine the company's capabilities. 


\section{RESEARCH MethodolOGY}

The research methodology that will be used in this study is the Qualitative approach. This is done because of the limitations of the author in obtaining confidential company data and the agreement between the author and the company regarding the use of data that will be used during the preparation of this study so that the qualitative approach is the most appropriate approach to carry out this research.

Authors will collect data and study literature from various sources to obtain information about the situation of the industry around the company that is related to research, both internal or external data. The process of collecting these data the author obtained through several sources, namely PT Bio Farma (Persero) Annual Report, previous research containing additional information about the company's condition, and official articles that have information relating to PT Bio Farma (Persero).

\section{EXTERNAL ANALYSIS}

\section{A. PESTEL Analysis}

According to [1], [7] said that this analysis is to see how the environment in general consists of dimensions in a broad (macro) environment that affect directly and indirectly on companies in the industry. In analyzing the company's external conditions, the first Analysis Tool that the Author will use is PESTEL Analysis. There are 6 segments to be analyzed, namely Political/Legal, Economic, Socio-Culture, Technology, and Environment. The following is the company's external analysis using the PESTLE Analysis:

1. Political/Legal

In the political/legal analysis, [1] said that companies and governments try to influence each other. The company tried to be able to make the government in favour of the company.

There are provisions and challenges for food, drink, and pharmaceutical industries regarding the application of Law no. 33 of 2014, regarding Halal Product Guarantee (JPH Law), it will be a challenge for the pharmaceutical industry, especially PT Bio Farma (Persero).

As a state-owned company, PT Bio Farma (Persero) received Law No. 19 of 2003 concerning SOEs. To optimize its role and be able to maintain it in the development of a more open and competitive world economy. Management and supervision of SOEs must be based on the principles of good corporate governance. To date, PT Bio Farma (Persero) has routinely provided performance reports based on GCG principles in each of its Annual Reports.

Also, PT Bio Farma (Persero) also agreed with Law Number 40 of 2007 concerning Limited Liability Companies, one of the objectives of this Act concerning the use of GCG in the company. Because it will help the creation of an efficient, transparent, and efficient market with legislation. The establishment of a Limited Liability Company has two main interests, namely the interests of shareholders and stakeholders.

According to Government Regulation (PP) Number 76 in October 15, 2019 which was signed by the President regarding the addition of state capital participation in PT Bio Farma's share capital, which is also included by government shares in PT Kimia Farma and PT Indofarma. Bio Farma was approved as the holding company of a pharmaceutical company that oversees PT Kimia Farma Tbk, and PT

\section{Indofarma Tbk.}

In 2016, WHO has declared of Polio Eradication because this disease is continuing to decrease in number of cases. So, WHO has stopped the production of Polio Type 2. While this product is the main contributor in export sales of PT Bio Farma (Persero).

\section{Economy}

In 2014-2018 that the processing industry itself consists of the Migas and Non-Migas Sectors has a good contribution to the Gross Domestic Product (GDP). Where the Non-Oil and Gas Industry Sector consists of various industrial commodities. And as can be seen in Figure 2.3 that the Chemical, Pharmaceutical, and Traditional Medicine Industries have the second-largest contribution from the NonOil and Gas Industry at $1.68 \%$.

So that the pharmaceutical industry itself has an important role in the economic growth in Indonesia. This will also encourage the government to be more supportive of the development of companies engaged in the pharmaceutical industry.

Besides that, Bio Farma has a challenges to reduce importing produk of their raw materials, because $90 \%$ of pharmaceutical raw materials/Active Pharmaceutical Ingredients (API) come from import product.

3. Socio-cultural

Until now the quality of public health in Indonesia is still very poor, according to the Global Health Index in 2017, Indonesia ranks 101 st out of 149 countries in its public health index,

For example, the awareness of the Indonesian people to vaccinate is still very low. This things occur due to various factors, such as the high level of poverty and people's purchasing power to vaccinate, the community's lack of awareness of the importance of using vaccines, and the still high public doubts concern the content and the label of Halal products in vaccines.

But this is inversely proportional to the state of the global community that has begun to increase awareness of the effectiveness of vaccine products on their health. In 2018 Public trust in the function of vaccines globally $84 \%$ believe in vaccines is effective to increase their health quality, but that fact has differences in each country

\section{Technology}

In the pharmaceutical industry, Indonesia has been awarded as a Center for Excellence in Biotechnology and has support to developing the Biotechnology by OKI. With the advantages of applying Biotechnology, it is expected that the pharmaceutical industry can improve capabilities in the research and development of new pharmaceutical products. So as to accelerate the time of research and development.

In the application of biotechnology in the pharmaceutical industry, especially vaccine and anti-sera producers, it is possible that the $\mathrm{RnD}$ or production process can reduce or no longer use animal origin/ingredients, but still produce safe, quality and efficacy products.

\section{Environment}

In the pharmaceutical industry, the RND process and its production, of course, will use materials that contain chemicals that can pollute the surrounding environment and 
can endanger the ecosystem around the company, and the company has the potential to produce waste in the category of Toxic and Hazardous Material (B3). So with these conditions, companies must follow Government Regulation (PP) No. 85 of 1999 concerning the management of Toxic and Hazardous waste by continuing to anticipate the management of waste.

B3 waste generated by the company and the need to manage include, animal carcasses, metals, chemicals, clinical waste, product packaging, product rejects, and expired products. But now Bio Farma is quite good in handling the issue of pharmaceutical waste, because Bio Farma has implemented environmental management innovations through CSR initiatives, that is Waste Management. This is also the company's effort to avoid having fake vaccines circulating in the market.

\section{B. Porter's Five Forces Analysis}

According to [1], [7] said that industry is a group of companies that produce products that are close substitutes. Analysis of the industry was carried out using Porter's Five Forces consisting of 5 factors, namely Threat of New Entrants, Bargaining Power of Suppliers, Bargaining Power of Buyers, Threat of Substitutes, and Rivalry Among Existing Firms. Analysis of the industry will determine the level of attractiveness of the industry that affects the profitability that can be expected in the industry.

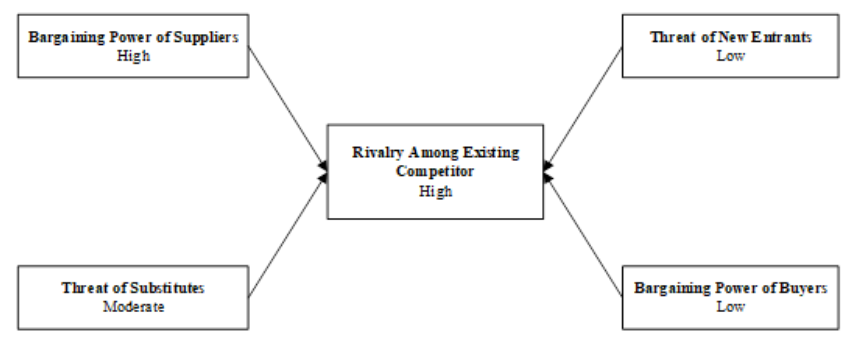

Fig. 1. Porter's Five Forces Analysis of PT Bio Farma (Persero).

As we can see from Figure 1, the conditions of Threat of New Entrants, Threat of Subtitutes, and Bargaining Power of Buyers is Low. For Threat of New Entrants its cause of the barriers to entry the industry is very difficult, the newcomers have challenge about economics of scale, product differentiation, capital requirements, switching cost, access to distribution channels, and government policy. Then for Threat of Subtitutes is Low because until now the vaccine is the only pharmaceutical product that is as a preventive actions to avoid several disesaes. And for Bargaining Power of Buyers is Low because in the pharmaceutical industry, both in Indonesia and abroad, there are very few companies that produce and sell vaccines. So, buyers in certain countries can only buy or use vaccines from certain companies that have distribution access in certain areas.

However, for Bargaining Power of Suppliers and Rivalry Among Existing Competitor is High. Because for Bargaining Power of Suppliers its cause because the raw materials used to produce vaccines that must have guaranteed quality and safety will affect the selection of good raw materials. So, it will be difficult to find and choose suppliers who can meet the qualifications of the company's requirements. So, the suppliers have a higher role, with quality products but limited quantity.

Then for Rivalry Among Existing Competitor its cause the development of emerging disease viruses is still occurring, and people are still consuming vaccines. This has caused all vaccine and bulk producer companies to continue researching to make new products. So, the product differentiation is relatively low. But what can distinguish is the effectiveness and safety of these products to cure and ward off disease. Then all vaccine producing companies continue to improve the quality of all their products to be able to maintain trust and expand their markets.

\section{Competitor Analysis}

According to [1] said that the analysis of competitors consists of four components, namely objective, assumption, strategy, and capabilities. It is necessary to analyze the strategic group of competitors in the industry. Strategic groups are companies in the industry that have similarities in their strategic dimensions. Competitor analysis focuses on companies that compete directly.

Analysis of the objective components of a competitor is related to future target competitors in terms of profits, revenues, asset values, and product diversification. Then the analysis of the assumptions determined by competitors against the industry implies the direction of development in the industry anticipated by competitors. Then an analysis of the strategies carried out by competitors implies the resources, activities, and superior competencies that competitors build to implement strategies. And the last is the analysis of capabilities will provide guidance on products and services that will be built.

The author will choose a company that is engaged in the pharmaceutical industry and has a vaccine product commodity in its business to conduct a competitor analysis. Based on statistical data regarding the global vaccine sales market share, the author will conduct a Competitor Analysis with the object of the GlaxoSmithKline plc, Sanofi, and Merck \& Co., Inc.

\section{Business Model CANVAS}

In this section the author will analyze the Business Model of PT Bio Farma (Persero) using the Business Model Canvas (BMC) framework. According to [2] said that the Business Model describes the rationale of how an organization creates, delivers, and captures value.

In the Business Model Canvas, there are Nine Building Blocks in which each Block has a relationship with each other so as to produce a value in each element. The nine building blocks include Customer Segments (CS), Value Propositions (VP), Channels (CH), Customer Relationships (CR), Revenue Streams (RS), Key Resources (KR), Key Activities (KA), Key Partnerships (KP), and Cost Structure (C\$). Figure 2 below shows the Business Model Canvas of PT Bio Farma (Persero). 


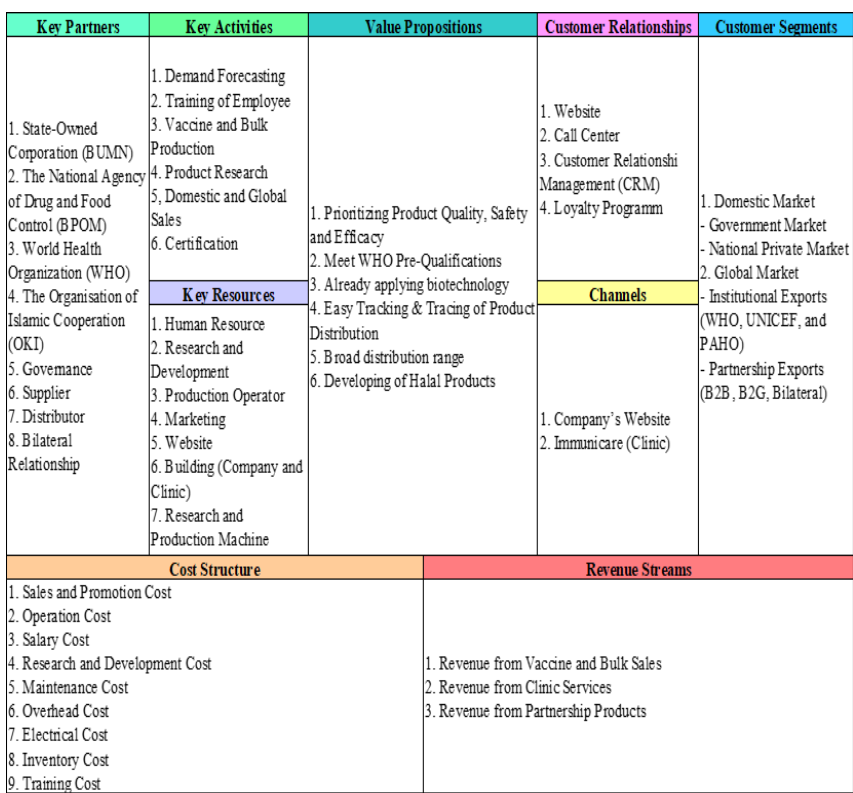

Fig. 2. PT Bio Farma (Persero) TOWS Matrix.

\section{TOWS MATRIX}

TOWS Matrix is a Systematic Tool that is used to create various strategies for companies by looking at the results of an analysis of the company's internal conditions (Strength and Weakness) and external (Opportunities and Threat). The Strength, Weakness, Opportunity, and Threat variables that used in this research through the SWOT Analysis. According to [3], [6] SWOT Analysis is the analysis to formulating strategies through Strength, Weakness, Opportunity, and Threat that obtain from internal and external analysis.

By using the analysis of the four conditions of the company, four forms of corporate strategy will be produced SO Strategies (Aggressive Strategy): Is a strategy used to maximize the company's internal strength to take advantage of opportunities from the company's external conditions, ST Strategies (Diversification Strategy): This is a strategy used to maximize the company's internal strength to avoid threats from the company's external conditions, WO Strategies (Turn Around): This is a strategy used to maximize the opportunities available by external companies to reduce the company's internal weaknesses, and WT Strategies (Defensive Strategy): This is s a strategy used to minimize weaknesses and threats that might occur.

The following is a table of the results of the company's strategy using TOWS Matrix for PT Bio Farma (Persero) based on the results of the SWOT analysis that the author made.

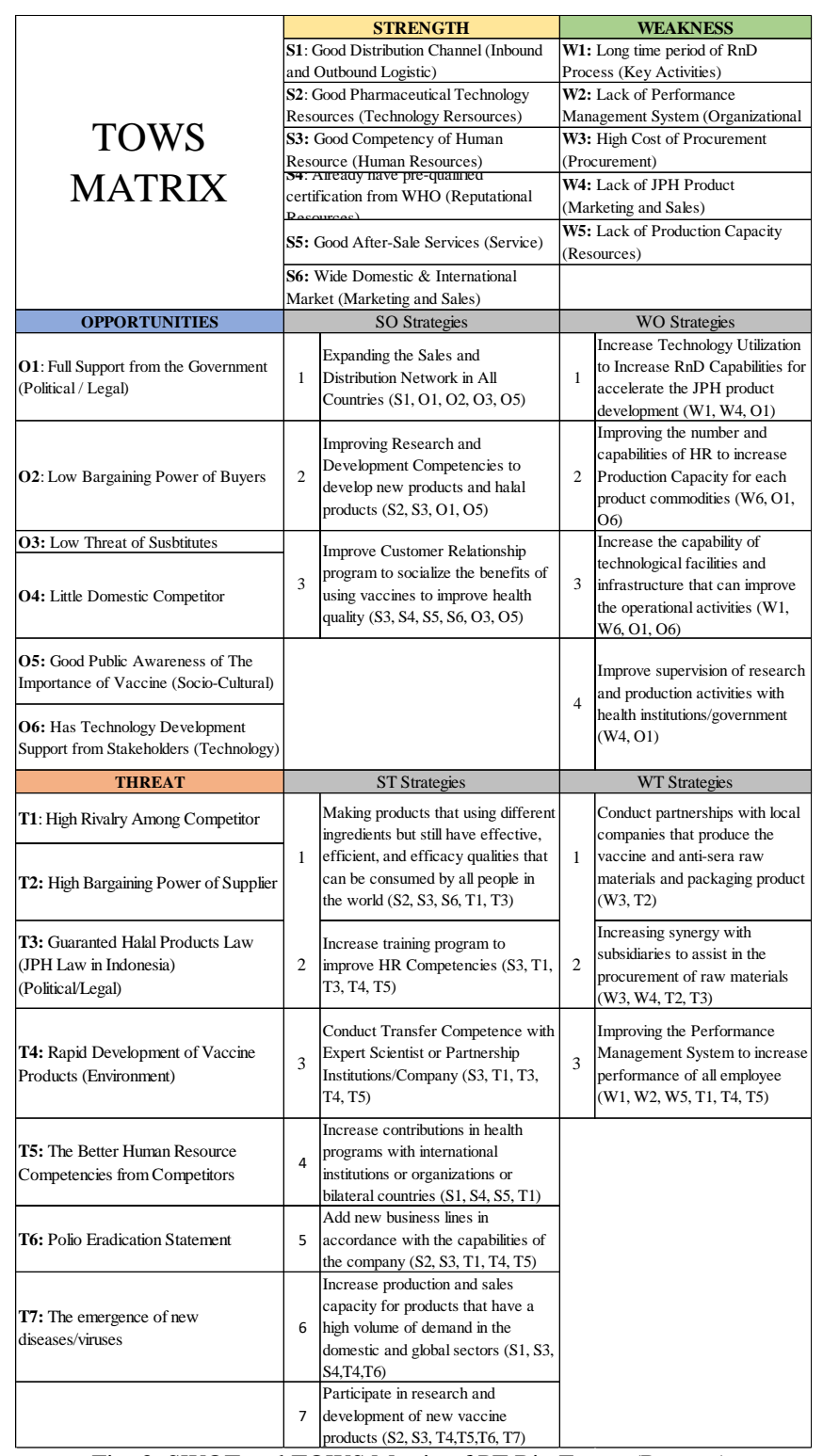

Fig. 3. SWOT and TOWS Matrix of PT Bio Farma (Persero).

\section{CONCLUSION}

The strategy that suitable fot PT Bio Farma (Persero) according to the external and internal conditions of the company to overcome the business issue such as JPH Law Products, High Rate of Importing Raw Materials, Decreasing in import sales, and Covid-19 Outbreak is through the Business and Corporate Strategy [4], [5].

For the Business Strategy, the company must change their strategy from Differentation Strategy to Integrated Costleadership/Differentiation. In Differentiation Strategy, company should accelerate the developing Halal Product by conducting collaboration with Government and Local/Global institution in developing Halal Product. But in Cost Leadership, the company should reduce their expense from importing the raw materials by conduction collaboration with subsidiary that can produce raw materials which can use by Bio Farma and improving the independency in pharmacy industry, improving Synergy between BUMN, and improve TKDN by reducing importing of raw materials.

For the Corporate Strategy, the company has to conduct Diversification Strategy in their business process to overcome 
the business issue about decreasing in export sales and Covid19 outbreaks. It can be done by Develop independently of new vaccine product that has high potential market, develop Covid-19 Vaccine independently or by partnership, increasing vaccine product that has the greatest number of needs, add new vaccine products for vaccines that have high sales potential, and create new business segment like Blood Product, and Bio Similar Products.

In this research, the author will suggest Strategic Maps as a guide for the company to implement the proposed strategy that the author proposed. The figure below is a strategic map for PT Bio Farma (Persero):

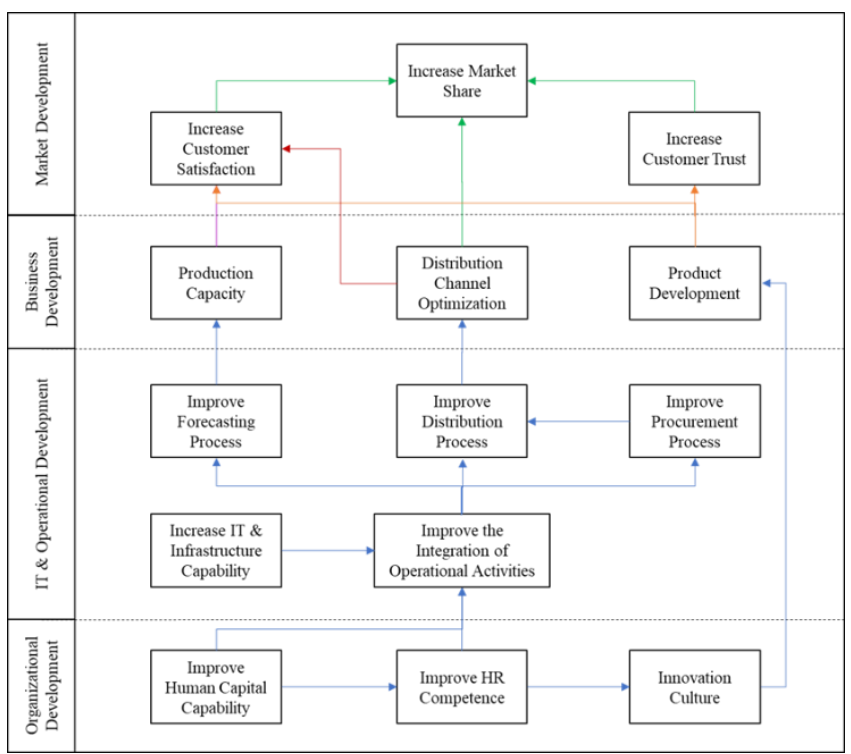

Fig. 4. Strategic Map.

After authors created a Strategic Map for Business Level Strategies in PT Bio Farma (Persero), the next step is to develop an organized process (Implementation Plan Timeline) that will be carried out by the companies. Below is a table of the Implementation Plan Timeline:

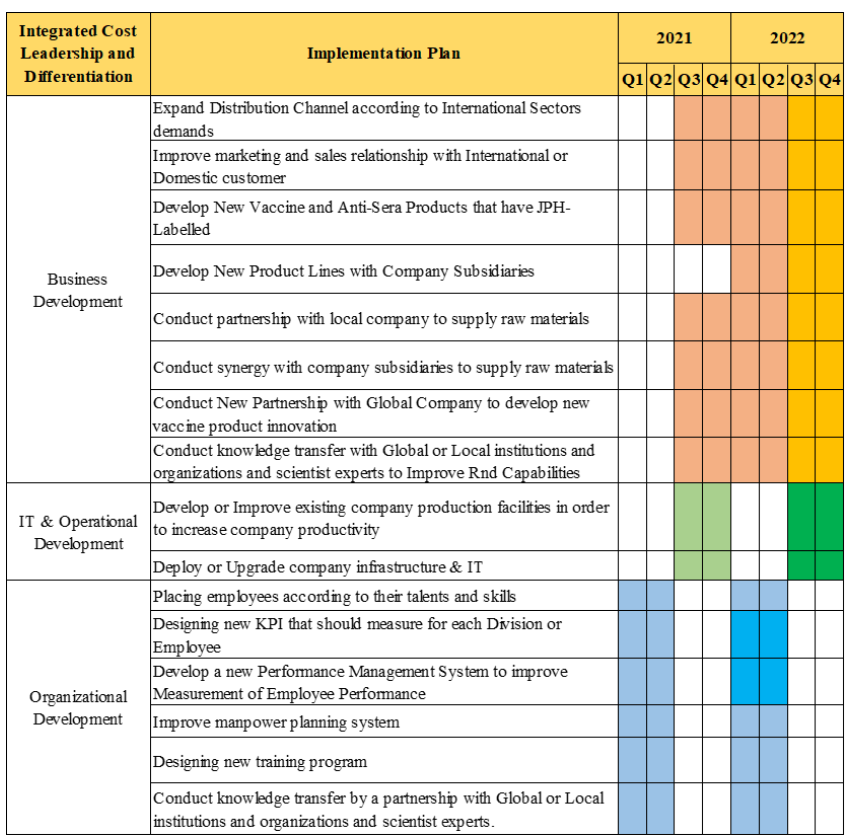

Fig. 5. Implementation Plan.

\section{REFERENCES}

[1] H. Wandebori, Manajemen Strategi Dalam Perspektif Indonesia Konsep dan Studi Kasus, Bandung: ITB Press, 2019.

[2] Osterwalder, A., \& Pigneur, Y. Business Model Generation, Hoboken, N.J: John Wiley \& Sons, Inc, 2010.

[3] Rangkuti, F, SWOT Balanced Scorecard. Jakarta: PT Gramedia Pustaka Utama, 2011.

[4] Hitt, M. A., Ireland, R. D., \& Hoskisson, R. E, Strategic Management: Competitiveness \& Globalization: Concepts and Cases (7th ed.), Mason, Ohio: Thomson South-Western College Pub, 2007.

[5] Hitt, M. A., Ireland, R. D., \& Hoskisson, R. E, Strategic Management: Competitiveness \& Globalization: Concepts and Cases (12th ed.), Boston: Cengage Learning, 2017.

[6] Kotler, P., \& Keller, K. L., Marketing Management (13th ed.), Upper Saddle River, N.J: Pearson Prentice Hall, 2009.

[7] Porter, M. E., The Competitive Advantage: Creating and Sustaining Superior Performance, New York: Free Press, 1985.

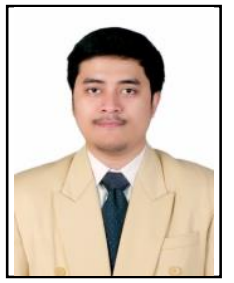

Reynaldy Prayogi, S.T. was born in Bandung, $26^{\text {th }}$ of February 1996. He earned his bachelor's degree in Industrial Engineering from Telkom University. $\mathrm{He}$ continued his postgraduate education in Business Administration at Bandung Institute of Technology, Indonesia majoring in Business Strategy.

He hass work experience as an intern at PT Bio Farma (Persero) in 2019 as a PPIC Staff and at PT Tekekomunikasi Indonesia (Persero) as an Engineering and Deployment Project Staff). Research Topics that have been carried out are related to Project Management and Performance Management.

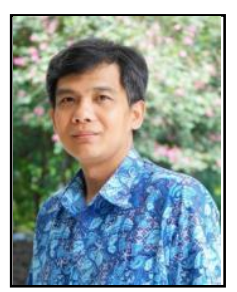

Harimukti Wandebori, S.T., MBA, Ph. D, is currently as an lecturer of Business Strategy and Marketing area at Master of Business Administration of Bandung Institute of Technology, Indonesia. He was completed his doctoral program at the University of Twente, the Netherlands in the International Strategic Alliance, and graduated in 2010. The research area that he has been cariied out are related to Strategic Alliance, Strategic Management, and Marketing 